\author{
І. М. Неклюдов ${ }^{1}$, Г. В. Громов ${ }^{2}$, \\ Н. П. Валігун ${ }^{2}$, А. В. Носовський ${ }^{2}$
${ }^{1}$ Національний науковий центр "Харківський фізико- технічний інститут"
${ }^{2}$ Державний науково-технічний центр з ядерної та радіаційної безпеки

\section{Щодо вдосконалення}

\section{системи науково-} технічної підтримки Держатомрегулювання України

Розглянуто сучасний національний та міжнародний досвід діяльності організацій з науково-технічної підтримки органів регулювання ядерної та радіаційної безпеки. Сформульовано вимоги та стратегічні завдання щодо вдосконалення системи науково-технічної підтримки Державного комітету ядерного регулювання України.

\section{И. М. Неклюдов, Г. В. Громов, Н. П. Валигун, А. В. Носовский \\ О совершенствовании системы научно-технической поддержки Госатомрегулирования Украины}

Рассмотрен современный национальный и международный опыт деятельности организаций по научно-технической поддержке органов регулирования ядерной и радиационной безопасности. Сформулированы требования и стратегические задачи по совершенствованию системы научнотехнической поддержки Государственного комитета ядерного регулирования Украины.
$\mathrm{P}$

егулювання безпеки у сфері використання ядерної енергії тісно пов'язано з необхідністю вирішення чисельних і складних проблем науковотехнічного характеру. Загальноприйнятою та найбільш ефективною міжнародною практикою $\epsilon$ створення при регулюючому органі організації технічної підтримки. Науково-технічну підтримку регулювання ядерної та радіаційної безпеки орієнтовано на виявляння, ідентифікацію та визначення шляхів розв'язання проблем регулювання [1].

Міжнародне ядерне співтовариство на цей час не сформулювало загальноприйнятого визначення терміну “організація науково-технічної підтримки" (Technical and Scientific Support Organization). Не містить його й Глосарій з безпеки МАГАТЕ [2]; у деяких керівництвах МАГАТЕ використовується термін "призначена організація підтримки" [3], але теж за відсутності його тлумачення. Отже, документально визначеного поняття, які організації, що залучаються до діяльності з регулювання безпеки в ядерній галузі, мають вважатися організаціями науково-технічної підтримки (ОНТП), або які характеристики відрізняють їх від інших науковотехнічних чи наукових організацій, не існує.

Метою статті є аналіз сучасного національного та міжнародного досвіду діяльності організацій з науково-технічної підтримки органів регулювання ядерної та радіаційної безпеки, формулювання вимог до таких організацій та напрямів діяльності.

\section{Міжнародний досвід}

Враховуючи, шо на даний момент наявність ОНТП має велике значення для забезпечення ядерної безпеки як з точки зору регулювання, так і експлуатації, МАГАТЕ у 2007 р. організувало й провело конференцію з цього питання. У матеріалах конференції [4] визначено, що організація науково-технічної підтримки - це організація, яка заснована з метою надання незалежної науково-технічної консультації або підтримки регулюючому органу чи експлуатуючій організації стосовно впливу на безпеку ядерних установок, діяльності у сфері ядерної енергії або іонізуючої радіації.

Правовий статус ОНТП у міжнародній практиці визначається, в основному, органом, для якого вона виконує науково-технічні роботи. В цьому розумінні важливо відрізняти ОНТП від “підрядників", що надають послуги ліцензіатам або операторам у проектуванні, виготовленні, спорудженні, установці, технічному обслуговуванні, аналізі безпеки установок або іншій діяльності. При цьому підрядник має той самий статус, що й ліцензіат або оператор, яким він надає свої послуги [5].

Багатосторонність питань ядерної безпеки обумовила необхідність у доступі регулюючих органів до відповідних наукових можливостей, який і забезпечується організаціями науково-технічної підтримки. Вважається, що у більшості випадків ОНТП мають пряме відношення до регулюючих органів та виконують тільки їх замовлення. Проте практика показує, що ізоляція наукової організації й зосередження ii завдань здебільшого на виконанні замовлень тільки регулюючого органу призводить до зниження професійного рівня експерта і невідповідності його визначенню як носія науково-технічного потенціалу в конкретній сфері знань або технічного оснашення. Лише здійснення спільних науково-технічних розробок і проектів з провідними науковими та проектними організаціями, вченими та 
інженерами ядерної галузі є запорукою підвищення та підтримання на високому рівні професіоналізму експерта. Єдиним та ефективним вирішенням зазначеного питання $\epsilon$ розширення сфери наукових досліджень та розробок за рахунок задоволення попиту на науково-технічну продукцію та послуги промислових структур ядерної галузі. Тому на практиці більшість організацій науково-технічної підтримки надають послуги не тільки для регулюючого органу, а й для експлуатуючих організацій (ліцензіатів). ОНТП для унеможливлення конфлікту інтересів при здійсненні наукових розробок на замовлення промислових структур та проведення державних експертиз цих проектів створюють відповідну систему управління, яка охоплює організацію, координацію та контроль за виконанням робіт, стандарти системи управління якістю, а також забезпечують зростання культури безпеки і розуміння співробітниками їх ролі в досягненні необхідного рівня якості виконуваних робіт і послуг, що характеризується наявністю високого морально-етичного рівня експертів.

ОНТП для надання науково-технічної консультації без тиску з боку регулюючих органів, промисловців або інших зацікавлених сторін повинна мати велику базу знань і відповідну інфраструктуру. Крім компетентності, ОНТП має володіти й відповідними ресурсами для ефективного виконання свого завдання, що полягає у надійній науковотехнічній експертній оцінці на запити зацікавлених сторін. Для постійного розвитку їі можливостей дуже важлива міжнародна співпраця, тому ОНТП слід найактивніше залучати до розробки стандартів МАГАТЕ і покращення режиму глобальної ядерної безпеки.

Міжнародна практика визначає такі основні функції регулюючого органу: встановлення стандартів, норм та правил з ядерної та радіаційної безпеки; ліцензування; нагляд та контроль; інформування громадськості; дослідження в регуляторній сфері. Організації науково-технічної підтримки можуть відігравати роль в усіх цих функціях, але кожна з цих функцій диктує свої вимоги до регулюючого процесу, зокрема такі.

Компетентність. Найважливішим фактором встановлення довіри суспільства до ОНТП є її науково-технічна компетентність у виконанні доручених завдань. Деякі ОНТП доводять таку компетентність свідоцтвом про атестацію або ліцензування державними урядовими органами. Органи державного регулювання ядерної безпеки деяких країн вимагають підтвердити, що ОНТП або її фахівці мають відповідну кваліфікацію. Одним із засобів встановлення технічної компетентності $€$ активна участь у спільних роботах з провідними науковими організаціями як на національному, так і міжнародному рівнях.

Рівень компетентності організацій, які надають науковотехнічну підтримку регулюючому органу, має гарантувати як готовність виконувати свої завдання та відповідати потребам регулюючого органу, накопичувати знання і досвід, розробляти й підтримувати необхідні засоби, забезпечувати трудові й фінансові ресурси, так і наявність відповідних систем управління, Перше, що ОНТП має передбачати у своїх стратегіях управління, - це те, як зберегти відповідний науково-технічний рівень і компетентність, необхідну для виконання своїх завдань, та ефективні засоби передачі знань наступним поколінням [8].

Одночасно з підтримкою технічної компетентності окремих осіб з числа персоналу, потрібні засоби для підвищення компетентності організації в цілому із забезпеченням відповідних трудових та фінансових ресурсів. Якщо трудовий ресурс ОНТП обмежений, до виконання деяких робіт можна залучати зовнішні організації, але з обережністю, щоб не призвести до зниження або втрати технічної компетентності ОНТП.

Ефективним засобом підвищення технічної компетентності регулюючих органів та ОНТП $є$ міжнародний обмін інформацією та знаннями, пов'язаними з безпекою, встановлення загального розуміння існуючих та майбутніх питань безпеки, а також розробка практичних підходів до вирішення таких питань.

Незалежність. Концепцію незалежності висвітлено міжнародною ядерною спільнотою в багатьох публікаціях [5], та, незважаючи на це, практичні аспекти досягнення незалежності для різних організацій і функцій залишаються предметом активного обговорення. Певна річ, ОНТП, яка надає підтримку регулюючому органу, не може бути повністю незалежною від політики регулювання або навіть деяких рішень, впроваджених регулюючим органом у межах його повноважень. ОНТП мусить працювати в рамках, встановлених регулюючим органом, що деякою мірою обмежує повну свободу іiї дій. Найголовнішим є те, що ОНТП, використовуючи свою професійну компетентність, незалежно від впливу зовнішніх тверджень має доводити свою дійсну незалежність від оператора. Важливим засобом досягнення незалежності може бути проведення експертної оцінки з безпеки для регулюючого органу одним персоналом ОНТП, а виконання технічного аналізу для експлуатуючої організації - іншим.

INSAG-17 [7] стверджує: "Важливо, щоб принципи та засоби забезпечення незалежності у прийнятті регулюючих рішень також застосовувалися для забезпечення незалежності та якості надання науково-технічних консультацій, передбачених функціями регулюючої підтримки, з відповідним налаштуванням на особливості їх науковотехнічної діяльності". Незалежність технічної консультації ОНТП від будь-якого зовнішнього впливу, наскільки це можливо, означає, що ОНТП повинна:

мати загальне уявлення про безпеку, дотримуватись довгострокової стратегії щодо розробки методів і правил з ядерної безпеки;

розробляти власні процеси оцінювання. Це означає, що ОНТП не керуватиметься обгрунтуваннями операторів, а оцінюватиме вплив на безпеку проектних заходів або процедур на основі своєї власної експертної оцінки;

мати змогу сприяти розвитку ядерної безпеки за допомогою визначення власних потреб у дослідженнях та результатів власних досліджень, а також використання результатів і досвіду інших організацій, включаючи операторів. Експлуатаційні дані, отримані від операторів, мають бути доступними для проведення досліджень ОНТП і навпаки;

співпрацювати з іншими ОНТП, дослідницькими центрами, університетами і спеціалізованими експертними організаціями. Така співпраця є необхідною, особливо у тих сферах, що не повністю охоплені ОНТП.

Прозорість та відкритість. Їнформація про загальну структуру, склад і діяльність окремої ОНТП має бути широкодоступною і відкритою. Довіра з боку будь-якої аудиторії постраждає, якщо аудиторія вважатиме, що певні сторони приймають важливі для безпеки рішення без відома суспільства або детального розгляду вповноваженими державними органами. В цілому, принцип максимальної відкритості щодо технічного аналізу має впроваджуватися всіма органами, які залучені до забезпечення ядерної безпеки (за винятком секретної інформації). Дуже важливо, 
щоб ОНТП надавала повну і точну інформацію регулюючому органу. У складних випадках регулюючі органи та оператори повинні проконсультуватися щодо способу розповсюдження в зрозумілій для суспільства формі технічної інформації з питань забезпечення безпеки без спричинення надмірного занепокоєння або проблем.

Етичність. Довіра до організацій, залучених до розвитку атомної енергетики, може підвишуватися тільки тоді, коли широка аудиторія вважатиме, що вони працюють на високому рівні, чесно й законно. Цей елемент виходить за межі доведення технічної компетентності. Він сконцентрований на етичних аспектах, а саме на надійності та справедливості ведення організацією та їі окремими фахівцями справ. Засоби для підтвердження етичності включають норми поведінки співробітників, правила і процедури для уникнення зловживання службовим станом, упередженості або дискримінації. Етичність має також економічний аспект. Оскільки більша частина робіт ОНТП виконується за контрактами по окремих проектах, необхідно вжити заходів для забезпечення відповідної законної оплати.

Ефективність. До найважливіших факторів належать економічні та планувальні. Для регулюючого органу може бути занадто дорого утримувати вузькокваліфікованих експертів для виконання завдань, які виникають лише на періодичній основі; обмеження кількості персоналу органів регулювання можуть ініціюватися Урядом. Тому з цієї точки зору стає привабливим створення окремої організації, яка фінансуватиметься не з державного бюджету, а із зовнішніх джерел. Однак ОНТП повинна бути спроможною своєчасно виконувати поставлені завдання так, щоб водночас із задоволенням потреб клієнтів кошти витрачалися раціонально. До ключових елементів ефективності належить також своєчасність виконання завдань.

Реагування та ініціатива. ОНТП можуть підвищити довіру за допомогою попереджувального відношення до потреб та інтересів їх клієнтів. Передбачання питань і проблем, а не пасивне очікування, допомагає довести, що на підтримку регулюючому органу з боку ОНТП і виконання iii обов'язків можна покладатися. Завчасна постановка питань, важливих для безпеки, але подекуди неочікуваних для клієнта, сприятиме уникненню надлишкових витрат і порушень. При цьому потрібно стежити за тим, щоб не створилося враження, що ОНТП просто шукає собі роботу лише заради прибутку.

Biдnовідальність. Суть цього елемента полягає в тому, що ОНТП бере на себе відповідальність за виконувану роботу. Якщо ж замовник вважає роботу ОНТП незадовільною, організація має бути готова до проведення коригуючих заходів. Відповідальність може включати контроль якості з встановленням внутрішніх адміністративних заходів для періодичного аналізу роботи. Якість підвищується чіткою й точною відповідністю нормативним документам і рекомендаціям, встановленим регулюючим органом або іншими державними установами і міжнародними організаціями.

Міжнародне наукове співтовариство виділяє для ОНТП, що надають підтримку регулюючому органу, такі сфери діяльності.

Розроблення правил і нормативних документів. ОНТП надають підтримку регулюючому органу в розробці правил, технічних керівництв та інших нормативних документів, а також в їх удосконаленні на основі обміну досвідом регулювання, сучасних науково-технічних даних та знань, з урахуванням міжнародних норм.
Ліцензування. Підтримка в ліцензійних питаннях включає ліцензування як діючих ядерних установок, так нових і модернізованих. Незалежний аналіз важливих питань безпеки необхідний, оскільки є надійним експертним аналізом технічних оцінок, проведених ліцензіатом.

Обмін досвідом з експлуатації. Обмін досвідом з експлуатації $€$ основним джерелом постійного підвищення ядерної безпеки i, таким чином, важливою сферою компетенції ОНТП.

Нагляд. Основною метою наглядової перевірки є підтвердження ліцензійного статусу об'єкта регулювання. Підтримка ОНТП включає визначення частоти та деталізації перевірки, а також перевірку результатів періодичного аналізу безпеки. Сюди можна віднести розробку ефективних і результативних регулюючих підходів і методів для вирішення технічних питань, включаючи оцінку та перевірку систем управління безпеки ліцензіата, культури безпеки, систем контролю якості, навчання персоналу, взаємодії з підрядниками, а також потенційний вплив на безпеку інших адміністративних, організаційних і людських факторів.

Науково-дослідні роботи. Важливою складовою діяльності ОНТП є їі компетентність у науково-дослідній сфері. Розрізняють основні та орієнтовані на регулювання науководослідні роботи; як для перших, так і для других потрібна надійна наукова база та різноманітні комп'ютерні програми. Основні науково-дослідні роботи виконуються для накопичення знань про важливі явища і для того, щоб бути обізнаним відносно сучасного стану досліджень безпеки. Науково-дослідні роботи, орієнтовані на регулювання, стосуються діяльності з сучасних питань регулювання безпеки і включають перевірку розрахунків ліцензіата. Важливим аспектом $є$ накопичення технічних знань для вирішення майбутніх питань, включаючи приховані недоліки поточних проектів, невідомі події або технічні проблеми, що не охоплюються сучасним інженерним досвідом, а також потенційні регулюючі питання, де не існує основних критеріїв.

ОНТП мають іти попереду технологічного розвитку, брати участь у державних і міжнародних дослідженнях та програмах розвитку для обміну інформацією і отриманим досвідом.

Хоча елементи науково-технічної підтримки однакові в усьому світі, ОНТП різних країн можуть суттєво відрізнятися. Так, Федеральне міністерство навколишнього середовища, охорони природи та безпеки ядерних установок Німеччини (BMU) $є$ федеральним наглядовим органом, який для здійснення науково-технічної підтримки залучає, насамперед, Товариство з безпеки установок і реакторів (GRS) [4]. Експертна оцінка GRS полягає, здебільшого, в проведенні основних науково-дослідних робіт, обміні досвідом по більш загальних аспектах експлуатації, підтримці BMU у розробці правил і нормативних документів та в інших питаннях безпеки. Така діяльність передбачає міжнародні зв’язки з іншими ОНТП і демонстрацію позиції Німеччини на міжнародному рівні. GRS окрім робіт для регулюючого органу також виконує роботи на замовлення експлуатуючих організацій.

Національному органу регулювання ядерної безпеки Франції ASN науково-технічну підтримку надає Їнститут радіаційного захисту та ядерної безпеки IRSN, який має штат фахівців 1500 чоловік з бюджетом біля 250 млн євро. Майже на суму 40 млн євро IRSN виконує роботи на замовлення експлуатуючих організацій [8]. 
У Фінляндії роль ОНТП полягає у наданні підтримки регулюючому органу (STUK) в рамках ліцензування. Загальною практикою ліцензування є те, що STUK замовляє ОНТП проведення незалежних аналізів безпеки, на підставі яких STUK робить заключні висновки. Вивчаючи питання будівництва нових AEC, STUK залучив багато державних та закордонних ОНТП [4]. Головною організацією, котра співпрацює зі STUK як ОНTП, є Центр технічних досліджень Фінляндії (VTT).

Організацією науково-технічної підтримки Комісії ядерного регулювання США (КЯР) є Управління досліджень ядерного регулювання (RES). RES надає технічні засоби, аналітичні моделі та експериментальні дані, потрібні для прийняття регулюючих рішень КЯР, проводить дослідження з метою підтримки ліцензійного і регулюючого процесу для підтвердження методів і даних, отриманих експлуатуючою організацією. Для забезпечення науково-технічних знань щодо прийняття регулюючих рішень у майбутньомy, RES стежить за розвитком промисловості та в разі потреби провадить спеціальні дослідження з метою підготовки КЯР до реагування на запити та ініціативи промислового сектора. Крім RES, Комісія ядерного регулювання США залучає багато інших організацій для виконання робіт з науково-технічної підтримки [4], в тому числі національні лабораторії США, які працюють на замовлення промислового сектора.

У 2007 р. з ініціативи деяких ОНТП було створено мережу Європейських ОНТП (ETSON), яка на сьогодні складається $з$ п'яти членів: GRS (Німеччина), IRSN (Франція), BelV (Бельгія), UJV (Ржеж, Чеська распубліка), VTT (Фінляндія) [9]. Метою цієї мережі є поширення в Європі науково-технічного співробітництва між ОНТП у сфері ядерної безпеки, що досягається, зокрема, шляхом систематичного обміну результатами науково-дослідних робіт, досвідом, пов'язаним з експлуатацією ядерних установок та оцінкою безпеки, поширення та гармонізації практики оцінки ядерної безпеки, а також заохоченням до розробки та впровадження Європейських дослідницьких програм. Це допоможе подальшому підвищенню сучасного міжнародного рівня науки та техніки завдяки використанню спільних ресурсів у всіх сферах роботи. Мережа заснована з перспективою відкритості цього співробітництва для інших європейських ОНТП. Рішення про членство приймається на зборах ETSON після розгляду заявки. Членство надається лише організаціям, які на регулярній основі здійснюють оцінку широкого кола питань безпеки на підтримку своїх національних регуляторів з ядерної безпеки або мають таку роль щодо глобального регулювання безпеки. ETSON є членом Платформи сталої ядерно-енергетичної технології (Sustainable Nuclear Energy Technology Platform) Європейської комісії. На цей час у форматі ETSON фактично створено три робочі групи для розробки тематичних документів з таких напрямів: керівництва з оцінки безпеки; визначення потреб у проведенні досліджень; управління знаннями. Мережа ETSON підтримує діяльність щодо посилення процесу європейського обміну експлуатаційним досвідом як важливого завдання з підвищення безпеки ядерних установок. Як внесок у цю діяльність, ETSON запропонувала створити Європейську систему для обміну досвідом експлуатації, до якої входитимуть:

Європейська експертна мережа, яка виконуватиме технічний аналіз та складатиметься з експертів ОНТП та регулюючих органів;
Технічна рада, яка допомагатиме процесу європейського обміну експлуатаційним досвідом та складатиметься з експертів високого рівня;

Їнформаційно-сервісний центр для координації робіт, розповсюдження результатів та виконання функцій контакту для країн-учасниць.

Виходячи з досвіду діяльності організацій науково-технічної підтримки, ОНТП та іншим зацікавленим сторонам надано рекомендації [4]; при цьому відмічено, що ініціативу в розв'язанні питань, які виникли у країн-членів стосовно ролі й діяльності ОНТП у підвищенні ядерної безпеки, має взяти на себе МАГАТЕ. Їнформацію про діяльність ОНТП, пов'язану з безпекою, необхідно включати до національних звітів, які надсилаються в рамках Конвенції про ядерну безпеку і Об’єднаної конвенції про безпеку поводження з відпрацьованим паливом та про безпеку поводження з радіоактивними відходами. Ця інформація має використовуватися для визначення й підвищення ефективності ОНТП.

\section{Вимоги до організаціїнауково-технічноїпідтримки}

Базуючись на міжнародному [3]-[5], [11] та національному досвіді [1], [8], [12]-[14], організація науково-технічної підтримки Державного комітету ядерного регулювання України (Держатомрегулювання) має бути наділеною правовими, технічними, виробничими та фінансовими можливостями для виконання власними силами основного обсягу робіт у цій сфері діяльності та, зокрема, мати:

необхідну інформацію та знання за напрямками безпосередньої діяльності регулюючого органу;

досвід науково-технічних робіт щодо безпеки об' $є$ ктів, які використовують ядерні та радіаційні технології;

досвід розроблення нормативно-правових документів з ядерної та радіаційної безпеки;

сучасну матеріально-технічну базу для виконання науково-дослідних робіт (обчислювальну техніку, захищені мережі, програмне забезпечення та ін.);

впроваджену та ефективно функціонуючу систему управління якістю;

підготовлений персонал, який пройшов необхідну зовнішню та внутрішню атестацію, перевірку знань норм і правил з ядерної та радіаційної безпеки в установленому порядку, а також має допуск до виконання робіт на об'єктах регулювання;

актуалізовану нормативну базу для виконання робіт за напрямками своєї безпосередньої діяльності;

необхідні спеціалізовані методичні документи та розрахункові коди, що забезпечують виконання робіт за напрямами безпосередньої діяльності.

До принципів, котрих має дотримуватись ОНТП і які формуються вимогами норм, правил і стандартів з ядерної та радіаційної безпеки, а також існуючою національною та міжнародною практикою, належать:

nріоритетність безпеки - основний принцип діяльності у сфері використання ядерної енергії, що передбачає безумовний пріоритет питань безпеки людини та навколишнього природного середовища перед економічними, політичними та (або) будь-якими іншими питаннями;

компетентність - наявність ресурсів, наукових та технічних можливостей для виконання повної та всебічної оцінки документації, наданої для проведення оцінки. До виконання роботи залучаються організації та кваліфіковані 
експерти з окремих вузькофахових напрямків оцінки, які мають необхідні ресурси, знання та досвід науково-технічної діяльності за відповідною спеціалізацією, що підтверджується необхідними документами згідно з процедурами, які встановлено регулюючим органом;

незалежність та об'єктивність - організація та експерти мають бути непричетними до розроблення проекту, що $\epsilon$ предметом експертної оцінки. Аналіз матеріалів з безпеки проводять експерти, які жодним чином не залучалися до підготовки цих матеріалів; вони повинні самостійно визначати методи аналізу та вільно викладати особисту думку з питань проведеного аналізу. Оцінки та висновки повинні базуватися на вимогах норм, правил та стандартів з ядерної та радіаційної безпеки, апробованих наукових дослідженнях, на досвіді експлуатації, застосуванні альтернативних засобів, програмного забезпечення, розрахункових моделей тощо. При виконанні робіт для регулюючого органу та експлуатуючої організації необхідно впровадити внутрішні процедури якості (наприклад, [13]), які забезпечують виконання робіт таким чином, щоб запобігти порушенням, дотримуючись встановлених законодавством норм і правил та принципу незалежності;

обтрунтованість рішень - прийняття рішень на підставі всебічної оцінки предмета експертизи на відповідність вимогам норм, правил та стандартів з ядерної та радіаційної безпеки, з урахуванням рекомендацій міжнародних організацій, сучасного світового досвіду та науково-технічних досягнень;

послідовність та системність - врахування результатів раніше виконаних оцінок та ухвалених на попередніх етапах регулюючих рішень, прогнозування особливостей наступних етапів ліцензійного процесу;

відповідальність - організація та експерти мають нести відповідальність за протиправне та (або) неякісне виконання робіт, за об’єктивність і повноту аналізу, обгрунтованість висновків.

Основними завданнями з науково-технічної підтримки Держатомрегулювання є:

забезпечення науково-технічної, дослідної, нормативноправової, експертної та інформаційної підтримки визначених напрямів науково-технічної діяльності;

розробка проектів норм, правил і стандартів з ядерної та радіаційної безпеки;

проведення наукових досліджень;

оцінка поточного стану ядерної та радіаційної безпеки ядерних установок, об'єктів поводження з радіоактивними відходами та радіаційних технологій, а також ризиків від їх запровадження;

виконання технічних експертних оцінок;

опанування, узагальнення та застосування передового досвіду аналізу та оцінки безпеки з відповідних напрямів діяльності;

підготовка аналітичних та інформаційних матеріалів.

ОНТП відповідно до покладених на неї завдань створює, підтримує та веде необхідні бази знань та банки даних; готує пропозиції до перспективних планів науково-технічних робіт; збирає та узагальнює відомості про сучасний світовий і національний науково-технічний рівні ядерної та радіаційної безпеки; інформує суспільство про результати діяльності через фахові видання та проведеня науково-технічних публічних заходів (конференцій, симпозіумів, семінарів тощо).

У рамках закріплених напрямів науково-технічної діяльності ОНТП відстежує світові тенденції розвитку, готує пропозиції шодо доцільності, умов та порядку їх впровадження в Україні; взаємодіє з іншими науковими організаціями суміжних напрямів діяльності.

ОНТП відповідає за якість і терміни виконання робіт згідно з чинним законодавством України та національними нормами, правилами і стандартами; забезпечує право власності замовника на науково-технічну документацію та інші результати діяльності; узгоджує із замовником умови використання науково-технічної документації та надання інформації третій стороні; своєчасно надає Держатомрегулюванню звіти про свою діяльність за встановленими формами та періодичністю.

\section{Стратегія розвитку науково-технічної підтримки}

Державний науково-технічний центр з ядерної та радіаційної безпеки (ДНТЦ ЯРБ) засновано відповідно до постанови Кабінету Міністрів України № 52 від 03.02.1992 р. 3 метою надання науково-технічної підтримки органу держаного регулювання ядерної та радіаційної безпеки. Для посилення позицій регулюючого органу, обгрунтування регулюючих рішень, реалізації основних принципів державного регулювання ядерної та радіаційної безпеки ДНТЦ ЯРБ виконує дослідження, які спрямовані на:

вивчення, адаптацію та запровадження в практику передових методологій виконання аналізу та оцінки безпеки; освоєння сучасних розрахункових кодів і розроблення моделей для отримання знань про перебіг процесів у компонентах реакторної установки;

аналіз існуючої системи нормування з метою виявлення неврегульованих аспектів, невизначеностей та протиріч; вивчення та аналіз досвіду експлуатації;

збір та аналіз вихідних даних для кожної реакторної установки; створення інформаційно-аналітичних та довідкових систем і баз даних;

впровадження методів імовірнісного аналізу безпеки в оцінки, пов'язані з надійністю обладнання, систем і елементів, міцністю конструкційних матеріалів;

ідентифікацію проблем безпеки, отримання знань щодо їх природи та можливостей вжиття коригувальних заходів.

Згідно із затвердженим Кабінетом Міністрів України планом заходів щодо реалізації Енергетичної стратегії України на період до 2030 року, перед Держатомрегулюванням постає низка нових відповідальних стратегічних завдань, що випливають із запланованої масштабної діяльності з розвитку ядерної енергетики країни. Тому для надання належної науково-технічної підтримки Держатомрегулюванню протягом найближчих років необхідно забезпечити відповідний розвиток системи науково-технічної підтримки.

На шляху до цієї головної стратегічної мети найважливішими цілями розвитку ДНТЦ ЯРБ, як організації з науково-технічної підтримки Держатомрегулювання, є:

забезпечення висококваліфікованої науково-технічної та експертної підтримки регулювання ядерної та радіаційної безпеки за всіма напрямами діяльності Держатомрегулювання;

пріоритетний розвиток напрямів, пов'язаних з діяльністю Держатомрегулювання у сфері удосконалення нормативного регулювання, впровадження сучасних методів регулювання безпеки;

підтримка та підвищення кваліфікації й професіоналізму співробітників підприємства, здобуття лідируючих позицій підприємства в галузі; 
зміцнення авторитету ДНТЦ ЯРБ на національному та міжнародному рівні.

Для досягнення зазначених стратегічних цілей потрібно забезпечити виконання у 2009-2012 рр. таких основних завдань.

1. Розширити потенціал науково-технічної діяльності ДНТЦ ЯРБ завдяки розвитку додаткових експертних можливостей та підсиленню оснащеності за деякими існуючими напрямками.

Це завдання може бути реалізовано зміцненням профільних наукових відділів, розширенням тематики та спектра їх задач; формуванням, за необхідності, нових наукових підрозділів; розширенням наукових зв'язків та розвитком співробітництва зі спеціалізованими науковими інститутами (галузевими, НАН України). Зокрема, у найближчій перспективі ДНТЦ ЯРБ необхідно:

посилити аналітичні можливості та технічну забезпеченість за напрямками “Теплогідравліка" і "Міцність та надійність конструкцій ядерних установок” за рахунок оновлення парку розрахункових кодів, сучасних експертних розрахункових моделей тощо;

поновити науковий потенціал за напрямком "Матеріалознавство";

розвинути розрахунково-аналітичні потужності у сфері застосування ймовірнісних методів та ризик-інформованих підходів (створення власних імовірнісних моделей для розв'язання задач у сфері регулювання);

підсилити та розширити експертні можливості за тематикою радіаційної безпеки, а також з питань, пов'язаних з реалізацією програми "Ядерне паливо України", розвитком уранового виробництва, радіаційним захистом від джерел випромінювання, які використовуються в медицині, та ін.;

проаналізувати можливість виконання робіт з верифікації та сертифікації розрахункових комп’ютерних кодів для використання у сфері ядерної енергетики;

розширити експертні можливості за тематикою фізичного захисту ядерних установок, об'єктів поводження з радіоактивними відходами і ядерними матеріалами, а також з питань забезпечення режиму гарантій нерозповсюдження ядерних технологій та матеріалів.

2. Сконцентрувати зусилля структурних підрозділів на вдосконаленні нормативної бази (особливу актуальність цей напрямок діяльності набуває внаслідок масштабності поставлених перед ядерною енергетикою України завдань у галузі законодавчого та нормативно-правового забезпечення реалізації Енергетичної стратегії України на період до 2030 року, а також з урахуванням необхідності гармонізації національних вимог з положеннями сучасних міжнародних стандартів). Для цього потрібно:

відповідно до розширення напрямків науково-технічної підтримки Держатомрегулювання України забезпечити розширення тематичного спектра участі ДНТЦ ЯРБ у розвитку нормативно-правової бази (охопити ділянки, пов'язані з утворенням ядерно-паливного циклу, фізичним захистом тощо);

сфокусувати поточні та нові проекти міжнародного співробітництва на розвитку нормативно-методологічної бази;

активізувати розробку нових та перегляд чинних норм і правил, які мають пріоритетне значення для регулювання безпеки (“Положення безпеки об'єктів з виробництва ядерного палива", "Правила устройства и безопасной эксплуатации оборудования и трубопроводов атомных энергетических установок" - ПНАЭ Г та інші документи колишнього СРСР); розробити загальний нормативний документ, який формулюватиме основні принципи застосування ризик-інформованих підходів та методів у діяльності з регулювання ядерної та радіаційної безпеки;

створити керівництва з використання ризик-інформованих підходів до прийняття рішень у регулюючих цілях при проведенні інспекційної діяльності, виконанні оцінки експлуатаційних подій, оцінки матеріалів з обгрунтування безпеки, що надає експлуатуюча організація.

3. Розробити та впровадити інтегровану систему регулювання безпеки АЕС.

Це завдання спрямоване на формування інтегрованої системи, яка дає змогу здійснювати об'єктивний контроль стану діючих енергоблоків АЕС та ефективно провадити регулюючу діяльність на підставі добре організованого моніторингу поточного рівня безпеки AЕC за сукупністю обраних критеріїв. Система має бути націлена на підвищення ефективності регулювання безпеки, забезпечення об'єктивності прийнятих рішень, своєчасне інформування громадськості. Приступити до формування такої системи можна за методологічної допомоги з боку Комісії ядерного регулювання США в рамках існуючої програми співробітництва. Для цього необхідно:

ініціювати розробку концепції інтегральної системи і поетапного плану іiі створення та впровадження на основі вивчення міжнародного досвіду;

розробити систему критеріїв та індикаторів, що дозволяють відслідковувати поточний рівень безпеки та зміни експлуатаційних показників діючих енергоблоків і концентрувати інспекційний контроль з боку регулюючого органу та самоконтроль з боку експлуатуючої організації на провідних факторах, які мають вирішальне значення для безпеки;

залучити до впровадження інтегральної системи експлуатуючу організацію, організувати дослідну експлуатацію системи на одному або кількох енергоблоках.

4. Розширити наукові зв'язки підприємства, міжнародне співробітництво та партнерські відносини з вітчизняними науковими організаціями та науково-виробничими підприємствами.

У цьому аспекті в першу чергу передбачається:

розвивати співробітництво з організаціями і підприємствами України та інших країн з питань безпеки ядернопаливного циклу (хімія урану, цирконію, властивості інших матеріалів, що застосовуються для виробництва ядерного палива, в тому числі властивості безпосередньо ядерного палива, тощо);

ширше та ефективніше використовувати можливості, що надаються програмами міжнародного співробітництва, розвивати нові напрямки;

активно використовувати можливості розвитку зв'язків з підрозділами НАН України, науково-дослідними інститутами, застосовуючи за додаткові механізми сумісне виконання наукових робіт, ініціювання спеціальних програм співробітництва, організацію та проведення тематичних наукових конференцій і семінарів, залучення провідних спеціалістів до діяльності науково-технічної та експертної рад тощо. Необхідно задіяти науковий потенціал НАН України для забезпечення всебічного розгляду в рамках державної експертизи матеріалів, які стосуються декількох галузей знань та мають інноваційний або складний міждисциплінарний характер.

5. Укріпити матеріально-технічну, аналітичну та інформаційну базу. 
ДНТЦ ЯРБ має володіти необхідними для забезпечення адекватної сучасним вимогам науково-технічної підтримки регулюючого органу матеріально-технічною базою, розрахунково-аналітичними засобами, доступом до сучасних інформаційних ресурсів, прикладними базами даних. Пріоритетними заходами для реалізації цього завдання є: масштабне оновлення та розширення існуючого парку спеціальних розрахункових програм для основних наукових підрозділів; розвиток корпоративної інформаційної системи, діяльності науково-технічної бібліотеки, поповнення фонду нормативних документів, ведення прикладних баз експертних та аналітичних даних.

6. Здійснювати планомірну підготовку та підвищення кваліфікації персоналу:

систематично планувати роботу з підготовки персоналу та підвищення кваліфікації співробітників, оцінювати ефективність іï реалізації;

розширити навчальні програми, залучивши до процесу підготовки кадрів організації та окремих фахівців НАН України;

зробити невід'ємною частиною підготовки персоналу, який бере участь у проведенні експертизи, періодичну перевірку знань вимог норм і правил з ядерної та радіаційної безпеки.

7. Вивчити та проаналізувати можливості організацій НАН України, підготувати пропозиції щодо науково-технічного співробітництва ДНТЦ ЯРБ з науковими інститутами НАН України, розробити спільну програму довгострокового співробітництва.

8. Вдосконалити систему збереження та управління ядерними знаннями (під управлінням знаннями розуміється інтегрований, систематичний підхід до процесів отримання, перетворення, поширення, використання, передавання й збереження інформації всередині підприємства).

Для реалізації цього завдання потрібно: розробити концепцію створення системи управління знаннями, структуру та основні технічні вимоги до неї на базі корпоративного інформаційного порталу; підтримувати в актуальному вигляді та постійно поповнювати існуючі бази даних; взяти участь у проекті створення порталу знань Держатомрегулювання.

9. Систематично освоювати міжнародний досвід: розвивати практику направлення співробітників ДНТЦ ЯРБ на навчання та стажування в рамках програм міжнародного співробітництва; розширювати обмін досвідом із зарубіжними партнерами в рамках програм міжнародного співробітництва.

\section{Висновки}

Ядерна та радіаційна безпека заснована на наукових, технічних, адміністративних, економічних і організаційних вимогах. У цьому відношенні роль і якість науковотехнічного забезпечення регулюючих рішень $є$ визначальними.
Організації науково-технічної підтримки, будучи або частиною регулюючого органу, або окремими установами, посідають все важливіше місце у створенні науково-технічного підгрунтя для прийняття рішень і провадженні діяльності, пов'язаної з ядерною та радіаційною безпекою. Враховуючи роль ОНТП, ці організації мають працювати за найвищими рівнями технічної компетентності, прозорості й етичності.

Для реалізації стратегічних цілій, наведених завдань та розвитку науково-технічного потенціалу ДНТЦ ЯРБ необхідно задіяти можливості НАН України. Першочерговими напрямками співробітництва з НАН України $є$ створення системи наукового супроводження елементів ядерно-паливного циклу, розвиток уранового виробництва, будівництво нових енергоблоків АЕС та дослідницького реактора.

\section{Список літератури}

1. Носовский А. В., Письменный Е. Н. и др. Введение в безопасность ядерных технологий: Уч. пособие. - К.: Техніка, 2006. - 360 с.

2. Глоссарий МАГАТЭ по вопросам безопасности. Термино логия, используемая в области ядерной безопасности и радиационной защиты. - Вена: МАГАТЭ, 2007.

3. Organization and Staffing of the Regulatory Body for Nuclear Facilities, Safety Standards Series № GS-G-1.1. - Vienna: IAEA, 2002.

4. Challenges Faced by Technical and Scientific Support Organizations in Enhancing Nuclear Safety (Proceedings Series). - Vienna: IAEA, 2007. - $297 \mathrm{p}$

5. Серия отчетов по безопасности № 11. Доклады по без опасности. Развитие Культуры безопасности в ядерной деятельности. - Вена: МАГАТЭ, 2000

6. Legal and Governmental Infrastructure for Nuclear, Radiation, Radioactive Waste and Transport Safety. Requirements Document, Safety Standards Series № GS-R-1. - Vienna: IAEA, 2000.

7. International Nuclear Safety Advisory Group, Independence in Regulatory Dicission Making. INSAG-17. - Vienna: IAEA, 2003.

8. Колесникова Н. М. Современное состояние и тенденции развития ядерной энергетики в странах западной Европы // Атомная техника за рубежом. - 2006. - № 4. - С. 11-17; № 5. - С. 3-15.

9. Creation of the European TSO Network. Memorandum of Understanding (MoU). Paris, 2008. $-3 \mathrm{c}$

10. Носовский А. В., Васильченко В. Н., Ключников А. А. Управление ядерными знаниями - необходимое условие реализации энергетической стратегии Украины //Ядерна та радіаційна безпека. - 2009. - Т. 12, вип. 2. - С. 56-60.

11. Гордон Б. Г. О тьме истин: Уч. пособие / Под ред. Ю. Г. Вишневского. - М.: НТЦ ЯРБ, 2003. - 301 с.

12. Барьяхтар В. Г., Ключников А. А., Носовский А. В. О необходимости реформирования науки в Украине и создания научноисследовательского института атомной энергетики // Проблеми Чорнобиля. - 2003. - Вып. 12. - С. 6-16.

13. Носовский $A$. В. Научные аспекты регулирования ядерной и радиационной безопасности //Ядерні та радіаційні технології. 2007. - T. 7, № $1-2$. - С. 38-45.

14. Сиспема управління якістю. Здійснення ДНТЦ ЯРБ науково-технічної діяльності на замовлення промислових інфраструктур ядерної галузі. Загальні положення. СТП 7.5/001.044:2005. - К., 2005.

Надійшла до редакції 02.09.2009. 